\title{
Atatürk Orman Çiftliği Arazisindeki Terkedilmiş Taş Ocaklarının Agropark Olarak Geri Kazanımı
}

\author{
${ }^{*}$ Merve YILDIZ YILMAZ1 \\ Nevin AKPINAR ${ }^{2}$ \\ ${ }^{1}$ Tarla Bitkileri Merkez Araştırma Enstitüsü Müdürlüğü, Ankara \\ ${ }^{2}$ Ankara Üniversitesi, Ziraat Fakültesi Peyzaj Mimarlığı Bölümü, Ankara \\ *Sorumlu yazar e-posta (Corresponding author; e-mail):merveyildiz006@gmail.com
}

Geliş Tarihi (Received): 19.03.2017

Kabul Tarihi (Accepted): 16.05.2017

\section{Öz}

Bu araştırmada, Atatürk Orman Çiftliği (AOÇ) arazi sınırları içinde bulunan terk edilmiş taş ocaklarının, tarım ve teknolojinin bir arada kullanıldığı agropark olarak kullanılabilirliği incelenmiştir. Bu bağlamda Çin'de kurulan Shangai Greenport Agropark master planında belirlenen kullanım tipleri değerlendirilerek, araştırma alanına uyarlanmıştır. Örnek uygulamada yer alan kullanım tipleri ticaret merkezi, iş merkezi ve merkezi işlem birimi olarak belirlemiş, Coğrafi Bilgi Sistemleri kullanılarak uygunluk analizleri yapılmıştır. Araştırma alanının doğal ve sosyo-kültürel özellikleri değerlendirilmiş, swot analizi yapılmıştır. AOÇ'nin tarihsel geçmişi de göz önünde bulundurularak gerçekleştirilen analizler sonucunda, taş ocaklarının agropark olarak değerlendirilmesinin uygun olduğu sonucuna varılmıştır. Böylece, terkedilmiş taş ocaklarının, tarıma yeni bir bakış açısı kazandıran agropark olarak değerlendirilmesi ile birlikte; araştırma alanının görsel kirlilik kaynağı olmaktan çıkıp, kente ekolojik, ekonomik ve estetik değer katan, kent halkı için yeni rekreasyonel faaliyetlere imkan veren kullanım alanı olması sağlanacaktır. Sürdürülebilir kent modeli için örnek teşkil edecektir.

Anahtar Kelimeler: Agropark, coğrafi bilgi sistemleri, peyzaj onarımı

\section{Rehabilitation of Derelict Quarries as Agropark in Atatürk Orman Çiftliği Area}

\section{Abstract}

This research involves performing analyses and developing suggestions for recovering the derelict quarries within the boundaries of Atatürk Orman Çiftliği (AOÇ) by turning them into agroparks where agriculture and technology go hand in hand. In this context, the usage types in the Shanghai Greenport Agropark master plan are assessed and adapted to the area of research. Usage types in the example are classified as commercial centres, business centres and central processing units; and conformity analyses are executed via Geographical Information Systems. Natural and socio-cultural characteristics of the research area are assessed and SWOT analysis is performed. As a result of the analyses carried out and considering the history of $\mathrm{AOC}$, it is concluded that it is appropriate to utilize quarries as agroparks. Therefore with abandoned quarries being utilized as agroparks through a new perspective to agriculture, the research area will no longer be a visual pollution resource but instead it will transform into an area of use that contributes ecologically, economically and aesthetically to the city and recreationally to the residents. It will serve as an example for the sustainable city model.

Keywords: Agropark, geographic information systems, landscape rehabilitation

\section{Giriş}

oplumların konut, sanayi, ulaşım gibi ihtiyaçlarının hammaddesini sağlayan taş ocaklarının işletilmesi kaçınılmazdır. Ancak taş ocağı işletmeleri sonucunda, toprak ve bitki örtüsü kayıpları, topografyadaki değişiklikler ve çok miktarlarda taş artıkları oluşmaktadır (Özcan 2009). Bu bağlamda üst toprak verimsizleşmekte ve üretim olanağı kalmamaktadır. Bitki örtüsünün tahribi ile buna bağlı olarak yaşayan fauna da kaybolmaktadır. Böylelikle rüzgar ve su 
erozyonu artmaktadır (Taşçıoğlu 2011). Ayrıca taş ocakları faaliyetleri sona erdirdikten sonra, peyzaj onarım çalışmaları yapılmadığı takdirde, ekolojik, ekonomik ve estetik açıdan birçok çevre sorununu da beraberinde getirmektedir (Akpınar 2000). Bu bağlamda onarım çalışmalarının aşamaları; peyzaj onarımının amaçlarının belirlenmesi, madencilik öncesi alanın yakın çevresinin derinlemesine envanterinin çıkarılması, madencilik faaliyetlerinin çevre üzerinde potansiyel etkilerinin belirlenmesi ve değerlendirilmesi (ÇED), madencilik faaliyetleri tamamlandıktan sonra onarılacak alanın son alan kullanımına karar verilmesi, uygulanacak alan kullanım planlamasına göre kendi kendini sürdürebilir bir bitki örtüsünün sağlanması, yapısal ve bitkisel uygulamaların desteği ile planlanan son alan kullanımının gerçekleştirilmesi, madenciliköncesikoşullardaki ekolojik ve sosyo-ekonomik değerlere eşit bir çevrenin yaratılması olarak sıralanabilir (Akpınar 1994). Taş ocağı madenciliği sonrasında alanlar, ziraat, orman, rekreasyon, sulak alanlar ve su kullanımı, inşaat alanı, yaban hayatı bölgeleri, bilimsel ve araştırma amaçlı kullanımlar için değerlendirilebilir (Ceylan ve Özkahraman 2000). Dünya ve Türkiye'den onarım örnekleri Çizelge 1'de verilmiştir.
Üretimini tamamlamış ve peyzaj onarımı sağlanmamış en çarpıcı örnek Atatürk Orman Çiftliği (AOÇ) arazileri içindeki terk edilmiş taş ocaklarıdır. AOÇ arazileri içinde \%3.6'ık kısmı kapsayan taş ocakları, yaklaşık 1022 dekar büyüklüğündedir (Çelik 2006). Ancak arazi, taş ocağı faaliyetleri sona erdikten sonra uzun süre kullanım dışı kalmıştır. Günümüzde ise toprak döküm sahası olarak kullanılmaktadır. Bu bağlamda mevcut durum; ekolojik, ekonomik ve estetik iyileşmenin sağlanabilmesi için peyzaj onarım araştırmalarının yapılması gerektiğini göstermektedir. Onarım önerileri kapsamında, araştırma alanının $A O C ̧$ ile bütünlüğünün sağlanabilmesi için AOÇ’nin kuruluş amaçları göz önünde bulundurulmalıdır. AOÇ'nin kuruluşunda, çiftçiye önderlik etmek için ilk aşamada tarım ve hayvancılık odaklı bir anlayış benimsenmiştir. Elde edilen ürünlerin işlendiği ve satışının gerçekleştirildiği ticari birimlere yer verilmiş ve kent halkının rekreatif faaliyetleri gerçekleştirebilmesi için olanaklar sağlanmıştır (Atak ve ark. 2004). Böylece modern tarımın nasıl yapılabileceği ve üretimin nasıl değerlendirilebileceği gösterilmiş ayrıca bu alanda uzmanların yetiştirilmesi amaçlanmıştır (Atak ve ark. 2004). Ancak kentleşmeye bağlı olarak, AOÇ'nin geçirmiş olduğu tarihsel

Çizelge 1. Taş ocağı onarım örnekleri

Table 1. Examples of quarry rehabilitation

\begin{tabular}{llll}
\hline ADI & KULLANIM TIPI & YERI & KAYNAK \\
\hline BUTCHART GARDEN & Taş ocağı üretimi bittikten KANADA & Anonymous \\
& sonra botanik bahçesine & $2012 a$
\end{tabular}

HALLER PARK dönüştürülmüştür

Taş ocağı üretimi sonrası KENYA Anonymous bölge parkına dönüştürülen 2012b alanda öncü bitkilendirme çalışmaları ile toprağın zenginleştirilmesi sağlanmış yaban yaşamı için uygun ortamlar oluşturulmuştur.

FOSSIL TRACE GOLF CLUB Kiltaşı ocağı dönüştürülerek ABD

Özcan 2009 golf sahası olarak kullanılmaya başlanmıştır.

SANTA CRUZ ÜNIVERSITESI Taş ocağı Santa Cruz ABD Anonymous Üniversitesi kampusunda Amfi 2017 tiyatro olarak kullanılmıştır. Taş ocaklarının çöp ve KONYA- Arık ve ark. hafriyatlarla doldurularak yeşil SELÇUK 2010 alana dönüştürülmüştür. Ayrıca alanın bir kısmının jeopark olarak kullanılması çalışmaları devam etmektedir.

Eski taş ocağı kapatılarak IZMiR-

Anonim 2017 toplu konut projesi uygulama KARŞIYAKA çalışmaları devam etmektedir. 
süreç, tarım odaklı planlama anlayışından uzaklaşılmasına neden olmuştur.

$\mathrm{Bu}$ kapsamda terkedilmiş taş ocaklarının onarımında, günümüz teknolojisine uygun tarımsal ve endüstriyel sistemlerle AOÇ'nin kuruluş felsefesine uygun bir model oluşturulmalıdır. Tarım ve teknolojinin bir arada kullanıldığı kompleks bir ağ olan agropark bu doğrultuda bir yaklaşım olacaktır.

Agropark, tarımsal fonksiyonların ve tarımla ilgili ekonomik faaliyetlerin mekansal bir kümesi olarak tanımlanmaktadır (Smeets 2009; Wolf ve Veen 2015). Agroparklar endüstriyel ekoloji ilkeleri çerçevesinde tarım ve tarım dışı eylemlerin gerçekleşmesine olanak sağlamaktadır (Carsjens 2015). $\mathrm{Bu}$ kapsamda, topraktan bağımsız üretim ve kaliteli yönetim zinciri oluşturulması, hayvansal üretimin kontrol altına alınması, atık ve yan ürünlerin karşılıklı kullanımının sağlanması, çiftçilerin pozisyonunun iyileştirilmesi, maliyetlerin azaltılması, kent-kır etkileşimi amaçlanmaktadır (Smeets ve ark. 2011). Ayrıca agroparklar, pazar dengesini kurması ve yenilenebilir enerji kaynaklarını tercih etmesiyle sürdürülebilirliği sağlamakta, kentleşme ve üretim alanları arasında bütünlük oluşturmaktadır (Kliebisch 2009). Ayrıca kent halkına rekreatif seçenekler sunmakta ve turizm faaliyetlerini arttırmaktadır (Kliebisch 2009).

Agroparkların planlanması ve uygulanması çok kompleks ve sistematik bir çalışma gerektirmektedir. $\mathrm{Bu}$ nedenle planlama çalışmaları; stratejik plan, master plan ve endüstriyel plan olarak gruplandırılmaktadır (Smeets ve ark. 2011). Stratejik plan; master plan ve endüstriyel planın kavramsal çerçevesini açıklayan planlama aşamasıdır. Mekânsal planlama, peyzaj ekolojisi, yönetim ve yönlendirme konularında ayrıntılı bilgilendirme sağlamaktadır. Master plan aşamasında, multidisipliner çalışma ile arazi kullanımları belirlenmektedir. Sürdürülebilirlik ilkesi doğrultusunda doğru ve akılcı çözümlerin üretilmesi bu aşamada gerçekleşmektedir. Endüstriyel planlama ise, üretim ve işleme faaliyetleriyle endüstriyel kalkınmanın sağlanmasını hedeflemektedir (Smeets ve ark. 2011). Agropark plan aşamaları, bütüncül yaklaşımla değerlendirilmelidir. Bununla birlikte planlama çalışmaları süreç odaklı olmalı ve katılımcı kalkınma politikası benimsenmelidir. Katılımcı kalkınma politikası; devlet, özel sektör, üniversiteler, sivil toplum kuruluşları ve yerel halkın işbirliğini esas almaktadır (Smeets ve ark. 2011). Böylece açık, hedefleri belli ve şeffaf bir planlama çalışması yürütülebilir.

Verilen bilgiler ışığında, tarım ve teknolojiye dayalı sanayinin geliştirilmesi yaklaşımının hem AOÇ'nde hem de agropark planlamasında benimsendiği görülmektedir. $\mathrm{Bu}$ ortak yaklaşım göz önünde bulundurularak yapılan araştırmada, AOÇ içindeki terk edilmiş taş ocaklarının, bilim ve teknolojiye dayalı tarımsal üretim olanakları sunan, tarım ve tarıma bağlı sektörleri canlandıran ayrıca kent halk için alternatif rekreatif faaliyetler içeren agroparka uygunluğunun ortaya koyulması amaçlanmıştır.

\section{Materyal ve Yöntem}

Araştırmada mevcut durumun belirtilmesi ve mekânsal analizlerin gerçekleştirilebilmesi için; Ankara Büyükşehir Belediyesi tarafından üretilen 1/1000 ölçekli haritalardan, Harita Genel Komutanlığı'ndan alınan i29b1 ve i29a2 numaralı paftalardan elde edilen vektör verilerden, Toprak Gübre ve Su Kaynakları Merkez Araştırma Enstitüsü tarafından hazırlanan $\mathrm{AOÇ}$ arazisi toprak etüt haritalarından, arazi çalışmaları sırasında çekilen fotoğraflar ve Google Earth uydu fotoğraflarından, AOÇ'nin tarihsel gelişim süreci ve agropark örnekleri ile ilgili incelenen yerli ve yabancı literatürden yararlanılmıştır. Mekânsal analizlerin gerçekleştirilmesinde ArcGIS10.0 programı kullanılmıştır.

Araştırma alanı, Ankara Büyükşehir Belediyesi tarafından 1954 yılında satın alınan 610.000 dekar arazinin taş ocağı olarak kullanılan kısmını kapsamaktadır (Anonim 2009). Bir süre kireçtaşı üretimi yapılan açık ocak işletmesi, üretimin sona ermesiyle 10 yılllık süre boyunca kullanım dışı kalmıştır. Günümüzde, alanın bir kısmında dolgu çalışmaları gerçekleştirilmiş ve ağaçlandırılmıştır.

Araştırma alanı, kuzeyde Ankara Çayı ve Limak Ankara Çimento, güneyde Sakıp Sabancı Bulvarı, güney batı da Zırhlı Birlikler Okulu ve Eğitim Tümen Komutanlığı, doğuda Anadolu Bulvarı ve batıda Etimesgut Yolu ile sınırlanmaktadır (Şekil 1). AOÇ’ne ait arazilerinden olması nedeniyle veri toplama ve plan kararlarının verilmesinde AOÇ ile bağlantının sağlanması esas alınmıştır.

Araştırma yönteminin aşamaları; literatür çalışmasının yapılması, araşııma alanının sınırlarının belirlenmesi, mevcut durumunun değerlendirilmesi (görsel değerlendirme, topografik yapı, erozyon risk durumu, toprak özellikleri, iklim özellikleri, su varlığı ve sosyokültürel özellikler), elde edilen veriler ışığında 


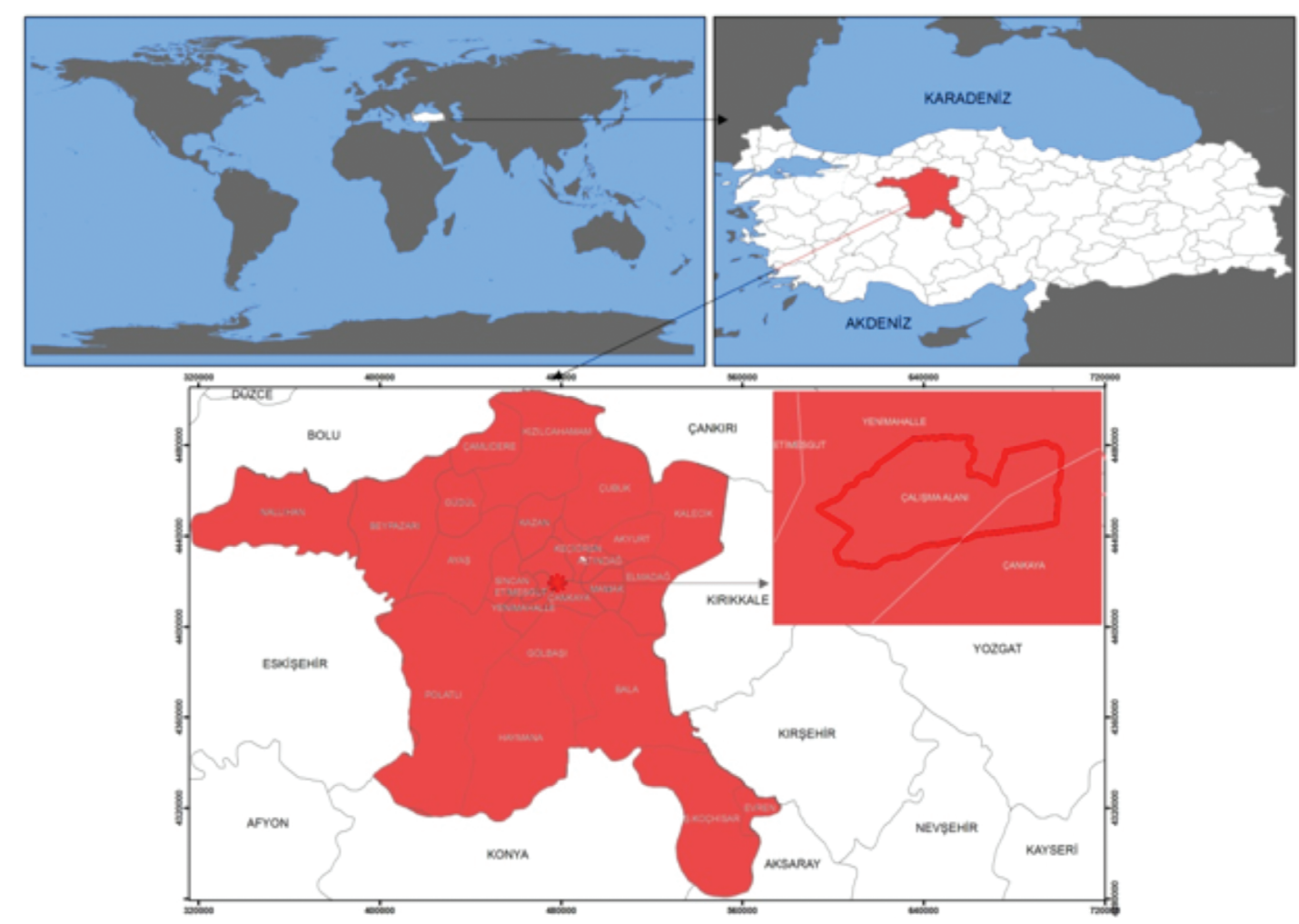

Şekil 1. Araştırma alanı lokasyonu

Figure 1. Location of research area

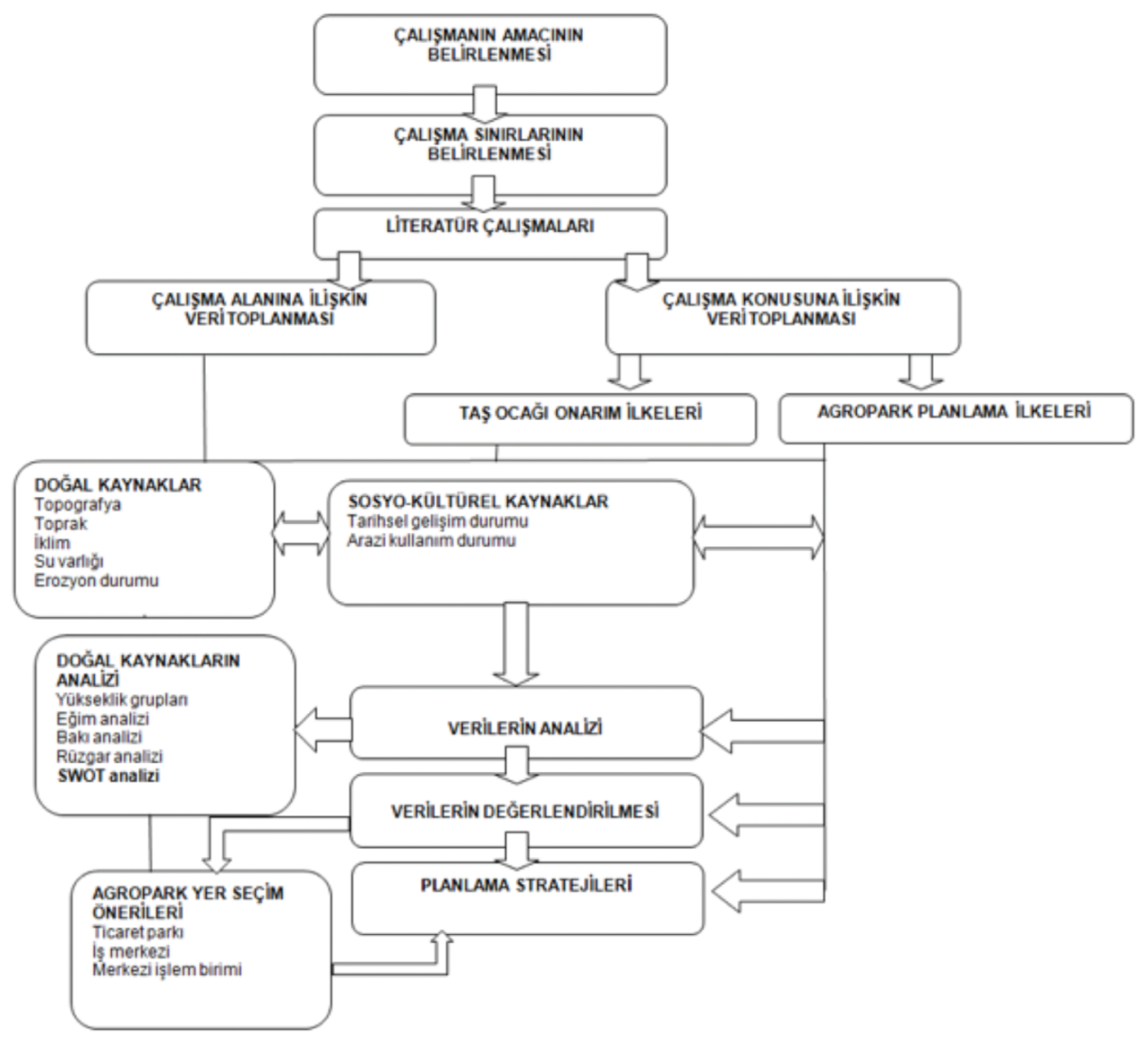

Şekil 2.Yöntem şeması

Figure 2. Methodolog 
analizlerin gerçekleştirilmesi (yükseklik grupları, eğim analizi, bakı analizi, rüzgar analizi, SWOT analizi), değerlendirme ve planlama stratejilerinin geliştirilmesidir (Şekil 2).

\section{Bulgular ve Tartışma}

Araştırma kapsamında elde edilen materyaller doğrultusunda, alandaki taş ocağı etkilerinin belirlenebilmesi için mevcut yükseklik verileri kullanılarak görünürlük analizi, yapılmış ve erozyon risk durumu, toprak özellikleri ve alandaki su varlığı haritalandırılmıştır. İklim özelliklerine ilişkin bilgiler verilmiştir. Ancak araştırma gerçekleştirildiğinde alanda iş makinelerinin çalışması nedeniyle flora ve fauna tespiti yapılamamıştır. Uzun yıllar boyunca taş ocağı olarak kullanılması nedeniyle literatürde bu bilgilere ulaşılamamıştır.

\section{Görünürlük Analizi}

Alanda taş ocaklarının etkisi; Sakıp Sabancı Bulvarından alınan bakış noktasından görülen büyük yükselti farkları ile oluşmuş sahalar ve çökelmiş araziler ile varlığını sürdürmektedir. $\mathrm{Bu}$ bağlamda görsel etkinin belirlenmesi için Anadolu Bulvarı ve Sakıp Sabancı Bulvarlarından görüş noktası alınmıştır ve araştırma alanının karayollarına yakın olan bölümleri görünür özellik gösterirken, toprak döküm sahalarının oluşturduğu tepelik alanların Ankara Çayı doğrultusundaki bölümlerin görünmesini engellediği sonucuna ulaşılmıştır
(Şekil 3). Araştırma alanındaki döküm sahaları ile oluşan yapay tepelik alanların ve bitki örtüsünün alandan uzaklaşmasının görsel kirlilik kaynağı olduğu saptanmıştır.

\section{Topografya}

Arazinin ortalama yüksekliğinin 880-885 m arasında değiştiği ancak toprak döküm sahasının üst noktasının $910 \mathrm{~m}$ olduğu görülmüştür (Şekil 4a).

\section{Erozyon Risk Durumu}

Toprak Gübre ve Su Kaynakları Araştırma Enstitüsünün hazırladığı haritalardan elde edilen toprak derinliği verileri ve alanın eğim özellikleri çakıştırılarak oluşturulmuştur (Çizelge 1). Bu bağlamda erozyon riski çok yüksek, yüksek, orta, düşük ve çok düşük olarak sınıflandırılmıştır. Taş ocaklarının bulunduğu alan ve çevresinin erozyon riskinin daha yüksek olduğu, Anadolu bulvarı ve Ankara Çayı'nın etrafında ise düşük olduğu görülmektedir (Şekil 4b).

\section{Toprak Özellikleri}

Toprak Gübre ve Su Kaynakları Araştırma Enstitüsü tarafından yapılan Atatürk Orman Çiftliği Detaylı Toprak Etüdü ve Haritalaması verilerinden araştırma alanını içeren kısımları alınarak oluşturulmuştur (Arcak ve ark. 2002). Bu bağlamda araştırma alanının toprak yapısı arazi kullanım kabiliyet sınıfları açısından değerlendirildiğinde arazide I, II, III, IV, V, VI,

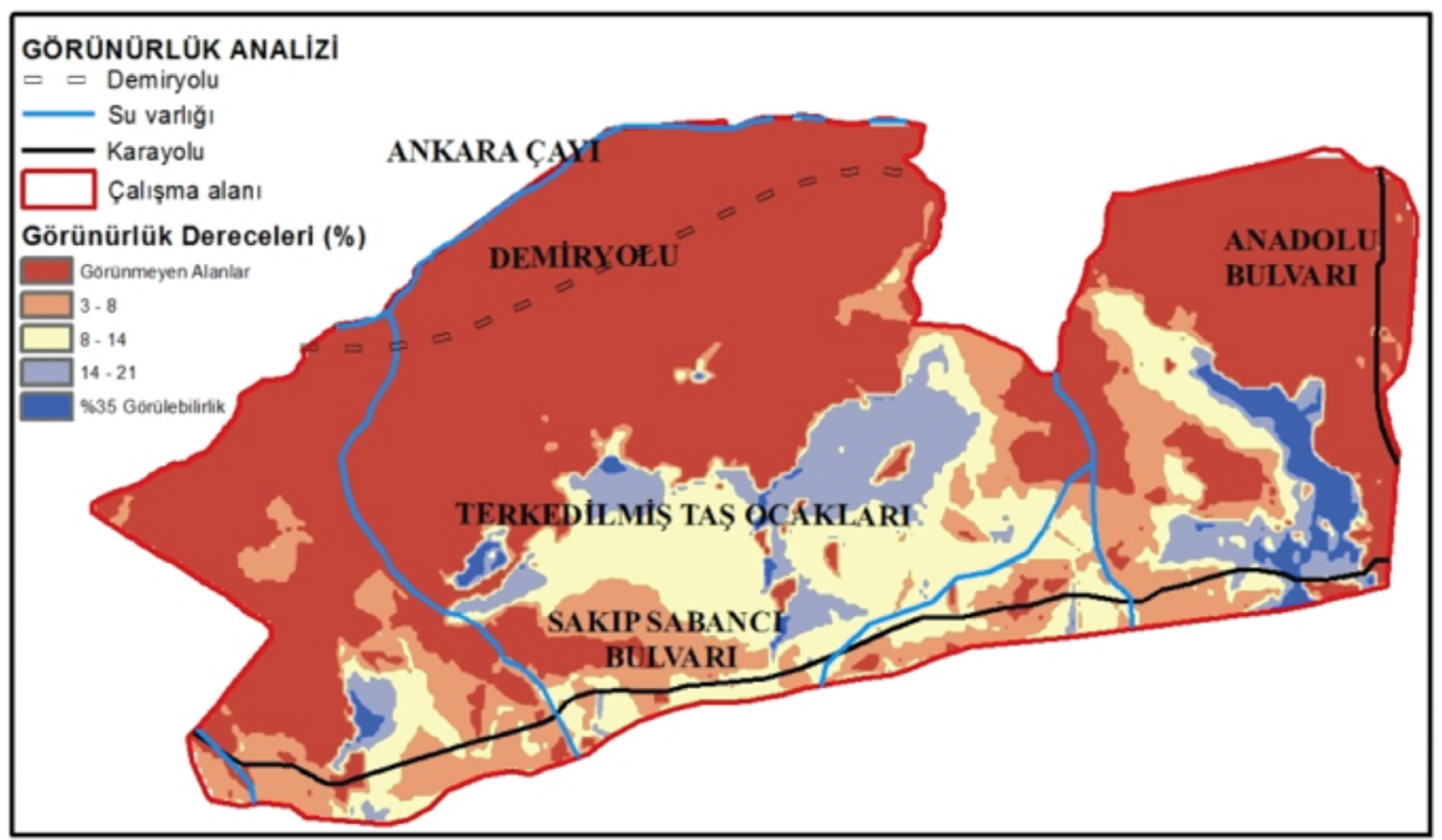

Şekil 3. Araştırma alanının görsel değerlendirmesi

Figure 3.Visual assessment of research area 
Yıldız Yılmaz ve Akpınar "Atatürk Orman Çiftliği Arazisindeki Terkedilmiş Taş Ocaklarının Agropark Olarak Geri Kazanımı"

Çizelge 2. Toprak derinliği ve eğim özelliklerine göre erozyon durumu (Anonim 2005)

Table 2. Erosion status according to soil dept and slope characteristics (Anonymous 2005)

\begin{tabular}{lcccc}
\hline & & \multicolumn{2}{c}{ DERINLIK $(\mathrm{cm})$} & \\
& ÇOK DERIN & DERIN & SIĞ & ÇOK SIĞ \\
& $>90$ & $50-90$ & $20-50$ & $0-20$ \\
\hline Düz-Düze yakın (\%0-2) & Çok düşük & Çok düşük & Düşük & Düşük \\
Hafif $(\% 2-6)$ & Düşük & Düşük & Orta & Orta \\
Orta (\%6-12) & Orta & Orta & Yüksek & Yüksek \\
Dik (\%12-20) & Yüksek & Yüksek & Çok yüksek & Çok yüksek \\
Çok dik (\%20-30) & Çok yüksek & Çok yüksek & Çok yüksek & Çok yüksek \\
Sarp $(>\% 30)$ & Çok yüksek & Çok yüksek & Çok yüksek & Çok yüksek \\
\hline
\end{tabular}

VII ve VIII sınıf arazilerin bulunduğu ancak II. Sınıf tarım arazilerinin daha fazla alan kaplamaktadır. Ayrıca arazi varlığının \%50'sinin tarımsal üretim için uygun niteliklere sahip arazi olduğu görülmektedir. Arazi varlığının \%35’e yakın kısmında ise tarım dışı faaliyetlerin yapılmasına olanak sağlanmaktadır (Şekil 4c).

\section{Su Varlığı}

Araştırma alanında, alanındaki en önemli su varlığı olan Ankara Çayı ve onu besleyen dereleri, dere yatakları ve vadi tabanları boyunca varlığını sürdürmektedir. Alanın su varlığına ve izlediği güzergaha ilişkin bilgiler Ankara Büyükşehir Belediyesinden elde edilen dijital verilerden yararlanılarak haritalandırılmıştır (Şekil 4d).

\section{İklim}

AOÇ arazisini de temsil eden Ankara kentinde hüküm süren iklim tipi step iklimidir. Ancak araştırma alanının kuzeyinde bulunan Ankara çayı ve yakın çevredeki yeşil alanlar mikroklimatik koşulların oluşmasına neden olmuştur. $\mathrm{Bu}$ bağlamda $\mathrm{AOÇ}$ ve çevresinde sıcaklıklar kent merkezine göre $1-2{ }^{\circ} \mathrm{C}$ daha düşük olmaktadır (Açıksöz 2001). Araştırma kapsamında yapılacak olan uygunluk analizleri için en önemli iklim parametrelerinde biri rüzgâr durumudur. Rüzgâr esme sayıları incelendiğinde, yıllık toplam esme sayısının en çok güneybatıdan $(4273 \mathrm{~m} / \mathrm{s})$, en az ise güneyden $(374 \mathrm{~m} / \mathrm{s})$ gerçekleştiği görülmektedir. Bunun yanı sıra $A O C ̧$ üzerinde

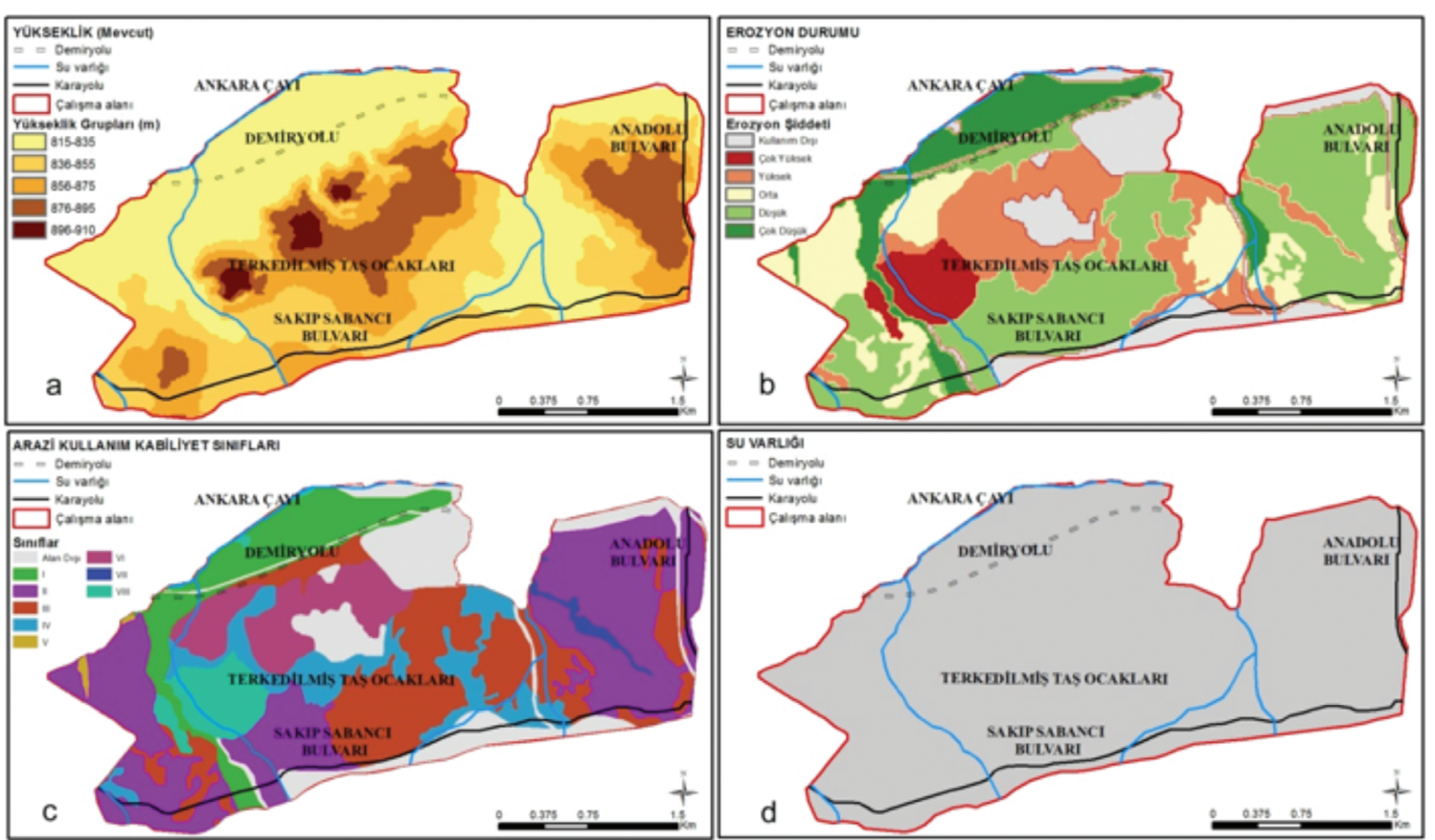

Şekil 4. Araştırma alanının mevcut doğal özellikleri (a; yükseklik durumu, b; erozyon risk durumu, c; arazi kullanım kabiliyet sınıfları, d; su varlığı)

Figure 4. Available natural characteristics of research area (a; elevation, b; erosion risk, c; landuse capability classes, d; hydrology) 
kuzey ve kuzeydoğu rüzgârları da etkili olmaktadır (Açıksöz 2001).

\section{Sosyo-Kültürel Özellikler}

Araştırma alanı AOÇ arazisinin bir parçası olduğu için AOÇ’nin tarihsel gelişim süreci ve arazi kullanım durumu değerlendirilmiştir. $\mathrm{Bu}$ bağlamda Atatürk'ün insan iradesiyle verimsiz topraklarda da tarım yapılabileceğini kanıtlamak için 1925 yılında kurduğu çiftlik 1937 yılında Devlet hazinesine devredilmiştir (Öztoprak 2006). Artan nüfus ve plansız kentleşme ile birlikte AOÇ arazi kayıpları yaşamış ve/veya çeşitli kullanımlara açılmıştır (Anonim 2009). Bu kayıpların önlenmesi için AOÇ 1938 yılında kurulan Devlet Ziraat İşletmeleri bünyesinde yer almıştır. Devlet Ziraat İşletmeleri'nin 1950'de kapatılması ile Devlet Ziraat İşletmeleri Müdürlüğü'ne geçmiştir. Arazi kayıpları önlenemeyince Atatürk Orman Çiftliği Müdürlüğü kurulmuştur (Anonim 2009). Günümüzde Gıda Tarım ve Hayvancılık Bakanlığı'na bağlı AOÇ Müdürlüğü tarafından yönetilmektedir. Ayrıca AOÇ Kültür ve Tabiat Varlıklarını Koruma Kurulunun 02.06.1992 gün ve 2436 sayılı kararı ile doğal ve tarihi sit alanı olarak tescil edilmiştir (Anonim 2009).

Alan kullanımı incelendiğinde ise $A O C ̧$ Müdürlüğü'ne ait sosyal tesisler, piknik alanları, lokantalar, yiyecek-içecek büfeleri,
AOÇ ürünleri satış birimleri, üretim tesisleri, ağaçlandırma alanları bulunmaktadır (Anonim 2009). Hayvanat bahçesi bölümü Ankara Büyükşehir Belediyesi tarafından Ankapark olarak düzenlenmektedir.

\section{Verilerin Analizi}

Araştırma kapsamında doğal verilerin analizi yükseklik, eğim, bakı, rüzgâr başlıklarında gerçekleştirilmiştir. Ayrıca alanla ilgili daha uygun ve akılcı kararların alınabilmesi için SWOT analizi yapılmıştır.

\section{Yükseklik Analizi}

Yükseklik gruplarının toprak döküm sahalarında çok yüksek değerlere ulaşması ve homojen bir dağılıma sahip olmaması nedeniyle ArcGIS 10.0 yazılımı kullanılarak arazi modellemesi yapılmış ve toprak döküm sahalarında 910 m olan değer 885 m'ye düşürülerek çevresiyle uyumlu hale getirilmiştir. (Modellenen arazi ve mevcut durum). Verilerin analizleri modellenmiş arazi yüksekliklerine göre yapılmıştır (Şekil 5a).

\section{Eğim Analizi}

Araştırma alanının, eğim analizinde, \%0-5 eğim derecesine sahip alanların, 2205.60 da, \%5-10 4383.60 da, \%5-10 2071.52 da \%20-30 1041.08 da ve \%30-39 eğim derecesine sahip alanların ise 332.50 da olduğu görülmektedir (Şekil 5b).
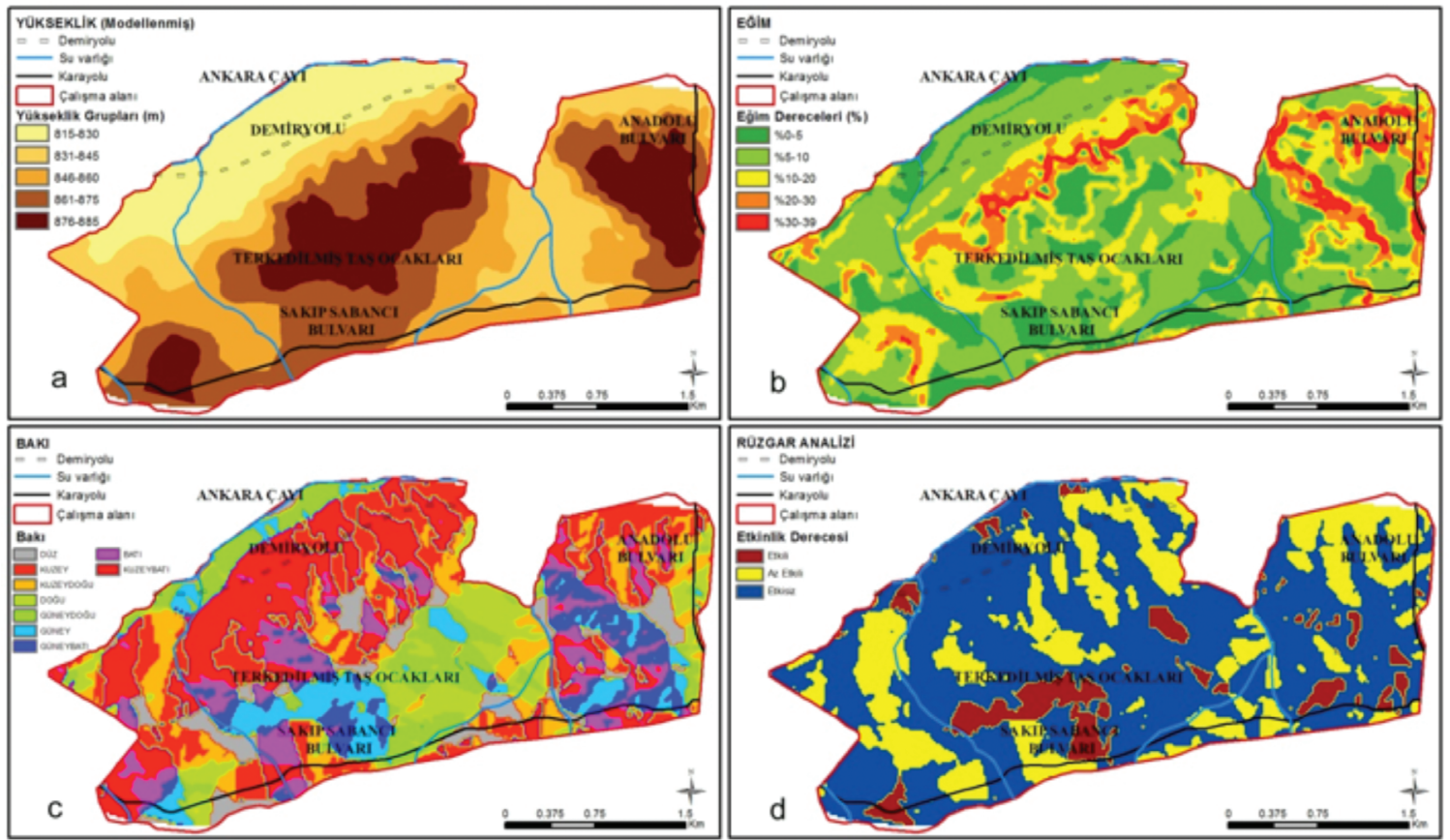

Şekil 5. Alanın doğal verilerinin analizi (a; modellenmiş yükseklik, b; eğim, c; bakı, d; rüzgâr)

Figure 5. Anaylsis of natural data (a; modeled elevaiton, b; slope, c; aspect, $d$; wind) 


\section{Bakı Analizi}

Araştırma alanın bakı analizinde alanın \%8'i düz, \%16'sı kuzey, \%11 kuzeydoğu, \%9 doğu $\% 10$ güneydoğu, \%8 güney, \%7 güneybatı, \%9 batı, \%22 kuzeybatı bakarlı alanlardan oluştuğu görülmektedir (Şekil 5c).

\section{Rüzgâr Analizi}

Bakı haritası temel alınarak hâkim rüzgar yönüne (güneybatı hâkim, kuzeydoğu ve kuzey etkili, doğu, batı, kuzeybatı, güney etkisiz) göre etkili, az etkili ve etkisiz olarak sınıflandırılmıştır. Alanın \%8'i rüzgârdan etkilenirken, \%27'si az etkilenmekte, \%65'i ise rüzgârdan hiç etkilenmemektedir (Şekil 5d).

\section{SWOT Analizi}

Bu aşamada alanın güçlü ve zayıf yönleri ile özelliklerinin vurgulanması, sunduğu fırsat ve tehditlerle peyzaj onarımı gerekliliğinin gösterilmesi amaçlanmıştır. Analiz, araştırma alanının kentsel bağlantısının sağlanabilmesi için AOÇ kapsamında gerçekleştirilmiştir. Bu doğrultuda AOÇ ve araştırma alanın lokasyonu, ekolojik özellikleri, mevcut durumu, sulak alan özellikleri, tarımsal faaliyetleri, rekreatif özellikleri ve kimliği değerlendirme kriteri olarak seçilmiş ve SWOT analizi yapılmıştır (Çizelge 3).

\section{Değerlendirme ve Planlama Stratejilerinin Geliştirilmesi}

Araştırma alanı, şehir merkezine yakınlığı, tarihsel gelişim süreci ve sahip olduğu ekolojik önem ile birlikte potansiyel bir güce sahiptir. Bu bağlamda üst ölçekte kent bağlantısını, yeni tarım tekniklerinin geliştirilmesini, tüketen kent olgusundan üreten kent olgusuna geçişi,

Çizelge 3. SWOT analizi

Table 3. SWOT analysis

\begin{tabular}{|c|c|c|c|c|}
\hline \multicolumn{5}{|c|}{ SWOT ANALIZi } \\
\hline KRITERLER & GÜÇLÜ YANLAR & ZAYIF YANLAR & FIRSATLAR & TEHDITTLER \\
\hline LOKASYONU & $\begin{array}{l}\text { Kent halkı tarafından } \\
\text { erişim kolaylığı }\end{array}$ & $\begin{array}{l}\text { Kentsel ulaşım } \\
\text { aksları arazi bütün- } \\
\text { lüğünü parçalamıştır }\end{array}$ & $\begin{array}{l}\text { Lokasyonu itibariyle } \\
\text { kent-kır planlama } \\
\text { anlayışına uygundur. }\end{array}$ & $\begin{array}{c}\text { Parçalı arazi } \\
\text { yapısına sahiptir }\end{array}$ \\
\hline $\begin{array}{l}\text { EKOLOJIKK } \\
\text { ÖZELLIKKLERI }\end{array}$ & $\begin{array}{l}\text { Açık yeşil alan } \\
\text { aksı oluşturmak- } \\
\text { tadır. (AOÇ,Hipod- } \\
\text { rum,Gençlik Parkı) }\end{array}$ & $\begin{array}{l}\text { Sınırları içindeki } \\
\text { fabrikaların atıkları } \\
\text { ile ekolojik denge } \\
\text { bozulmuştur. }\end{array}$ & $\begin{array}{c}\text { Ekolojik bir } \\
\text { potansiyel } \\
\text { barındırmaktadır. }\end{array}$ & $\begin{array}{l}\text { Uzun süreçli } \\
\text { ekolojik yenileme } \\
\text { gerektirmektedir. }\end{array}$ \\
\hline $\begin{array}{l}\text { MEVCUT } \\
\text { DURUMU }\end{array}$ & $\begin{array}{c}\text { Sosyal, kültürel } \\
\text { ve doğal kaynak } \\
\text { özelliklerinin tarihsel } \\
\text { önemi bulunmak- } \\
\text { tadır. }\end{array}$ & $\begin{array}{l}\text { AOÇ üzerindeki } \\
\text { kentsel baskı art- } \\
\text { maktadır. }\end{array}$ & $\begin{array}{c}\text { Kaynakların } \\
\text { sürdürülebilirliğini } \\
\text { sağlayacak önemli } \\
\text { bir peyzaj değeridir. }\end{array}$ & $\begin{array}{c}\text { Arazi bütünlüğü } \\
\text { korunamamaktadır. }\end{array}$ \\
\hline $\begin{array}{l}\text { SULAK ALAN } \\
\text { ÖZELLIGGi }\end{array}$ & $\begin{array}{l}\text { Ankara Çayı, AOÇ } \\
\text { sınırlarından geçme- } \\
\text { ktedir. }\end{array}$ & $\begin{array}{l}\text { Ankara Çayı } \\
\text { çevresini olumsuz } \\
\text { etkilemektedir. }\end{array}$ & $\begin{array}{c}\text { Ankara Çayı, } \\
\text { rekreasyonel, estetik } \\
\text { ve görsel açıdan } \\
\text { değerlendirilebilir. }\end{array}$ & \\
\hline $\begin{array}{l}\text { TARIMSAL } \\
\text { FAALI- } \\
\text { YETLER }\end{array}$ & $\begin{array}{l}\text { Tarımsal aktivitelerin } \\
\text { teknolojiyle birleştiril- } \\
\text { mesine imkanlar } \\
\text { sunmaktadır. }\end{array}$ & $\begin{array}{l}\text { Sınırları içindeki } \\
\text { tarım alanları işlev- } \\
\text { ini yitirmiştir. }\end{array}$ & $\begin{array}{l}\text { Kent-Kır planlama } \\
\text { modeliyle sürdürüle- } \\
\text { bilirliği sağlayacaktır. }\end{array}$ & \\
\hline $\begin{array}{l}\text { REKREATIF } \\
\text { ÖZELLİKLERİ }\end{array}$ & $\begin{array}{l}\text { Metropoliten alanda } \\
\text { kent halkının en } \\
\text { önemli rekreasyon } \\
\text { alanlarından biridir. }\end{array}$ & $\begin{array}{l}\text { Alanın büyük bir } \\
\text { kısmında halk } \\
\text { kullanımı mümkün } \\
\text { değildir. }\end{array}$ & $\begin{array}{l}\text { Tarımsal rekreatif } \\
\text { faaliyetler için } \\
\text { uygundur. }\end{array}$ & $\begin{array}{l}\text { Kamusal ilgi } \\
\text { eksikliği bulunmak- } \\
\text { tadır. }\end{array}$ \\
\hline KIMLLiĞi & $\begin{array}{l}\text { Modern başkentin } \\
\text { sembolüdür. }\end{array}$ & $\begin{array}{c}\text { Amaç dışı } \\
\text { kullanımlarla } \\
\text { kuruluş } \\
\text { felsefesinden } \\
\text { uzaklaşılmıştır. }\end{array}$ & $\begin{array}{l}\text { Kuruluş felsefine } \\
\text { göre tarım } \\
\text { odaklı planlama } \\
\text { ile üreten kent } \\
\text { oluşturulabilecektir. }\end{array}$ & $\begin{array}{l}\text { Kullanım dışı atıl } \\
\text { kalan alanlar kentin } \\
\text { prestijini olumsuz } \\
\text { etkilemektedir. }\end{array}$ \\
\hline
\end{tabular}


Çizelge 4. Ticaret parkı uygunluk analizi parametreleri Table 4. Trade park suitability analysis parameters

\begin{tabular}{|c|c|c|c|c|c|c|c|}
\hline \multirow{2}{*}{\multicolumn{2}{|c|}{$\begin{array}{c}\text { TICARET PARKI } \\
\text { BIRIMLERI }\end{array}$}} & \multicolumn{6}{|c|}{ UYGUNLUK SINIFLARI } \\
\hline & & YÜKSEKLIKK & EĞìM & BAKI & EREZYON & AKS & RÜZGAR \\
\hline \multirow{4}{*}{ 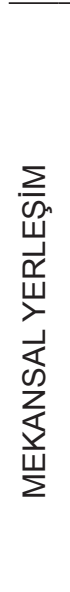 } & $\begin{array}{c}\text { MEYVE } \\
\text { BAHÇELERI }\end{array}$ & $\begin{array}{l}815-830 \\
831-845 \\
846-860\end{array}$ & $\begin{array}{c}\% 5-12 \\
\% 12-20 \\
\% 20-30\end{array}$ & $\begin{array}{l}\text { Kuzey } \\
\text { Doğu }\end{array}$ & $\begin{array}{l}\text { Hiç } \\
\text { Çok az } \\
\text { Orta }\end{array}$ & III,IV & - \\
\hline & $\begin{array}{l}\text { ÜRETIM } \\
\text { SERALAR }\end{array}$ & - & $\% 0-5$ & $\begin{array}{l}\text { Güney } \\
\text { Güney D. } \\
\text { Doğu } \\
\text { Batı }\end{array}$ & - & - & $\begin{array}{l}\text { Rüzgar } \\
\text { Almayan }\end{array}$ \\
\hline & $\begin{array}{c}\text { AHIR VE KÜMES } \\
\text { HAYVANCILIĞI }\end{array}$ & - & $\begin{array}{c}\% 0-5 \\
\% 5-10\end{array}$ & $\begin{array}{l}\text { Güney } \\
\text { Güney D. } \\
\text { Doğu }\end{array}$ & $\begin{array}{c}\text { Hiç } \\
\text { Çdk az }\end{array}$ & $\begin{array}{l}\text { V, VI, } \\
\text { VII, VIII }\end{array}$ & $\begin{array}{l}\text { Rüzgar } \\
\text { Almayan }\end{array}$ \\
\hline & $\begin{array}{c}\text { TARIMSAL } \\
\text { REKREASYON }\end{array}$ & $\begin{array}{l}815-830 \\
831-845 \\
846-860 \\
861-875 \\
876-885 \\
\end{array}$ & $\begin{array}{c}815-830 \\
\% 0-5 \\
\% 5-12 \\
\% 12-20\end{array}$ & $\begin{array}{c}\text { Düz } \\
\text { Tüm bakarlar }\end{array}$ & $\begin{array}{l}\text { Hiç } \\
\text { Drta }\end{array}$ & $\begin{array}{l}- \\
-\end{array}$ & $\begin{array}{l}- \\
-\end{array}$ \\
\hline
\end{tabular}

AKS: Arazi kullanım kabiliyet sınıfı. Meyve bahçeleri (Akpınar ve ark. 2004), üretim seraları (Gezer 2006), ahır ve kümes hayvancılığı (Tıknazoğlu 2010), Tarımsal rekreasyon(Akpınar ve ark. 2004).

AKS: Land use capability class. Fruit gardens( Akpınar ve ark. 2004) greenhouse (Gezer 2006), farms (Tıknazoğlu 2010) Agricultural recreation (Akpınar ve ark. 2004).

tarım ve tarıma dayalı tüm sanayi ve ticaret kollarında gelişme sağlayan ve kent halkı için alternatif rekreatif faaliyetler sunan agropark planlaması ile bu potansiyel güç arttırılacaktır Tarım ve teknolojinin ekonomik, ekolojik ve estetik kaygıları göz önünde bulundurarak bir araya gelmesine olanak sağlayan agropark planlaması kapsamında birçok analiz ve değerlendirme çalışması yapılması gerekmektedir. Bu kapsamda planlama stratejilerinin geliştirilmesi için mekânsal dağılım yapılmıştır. Agropark birimleri ticaret parkı, iş merkezi ve merkezi işlem birimi olarak sınıflandırılmıştır (Smeets ve ark. 2011).

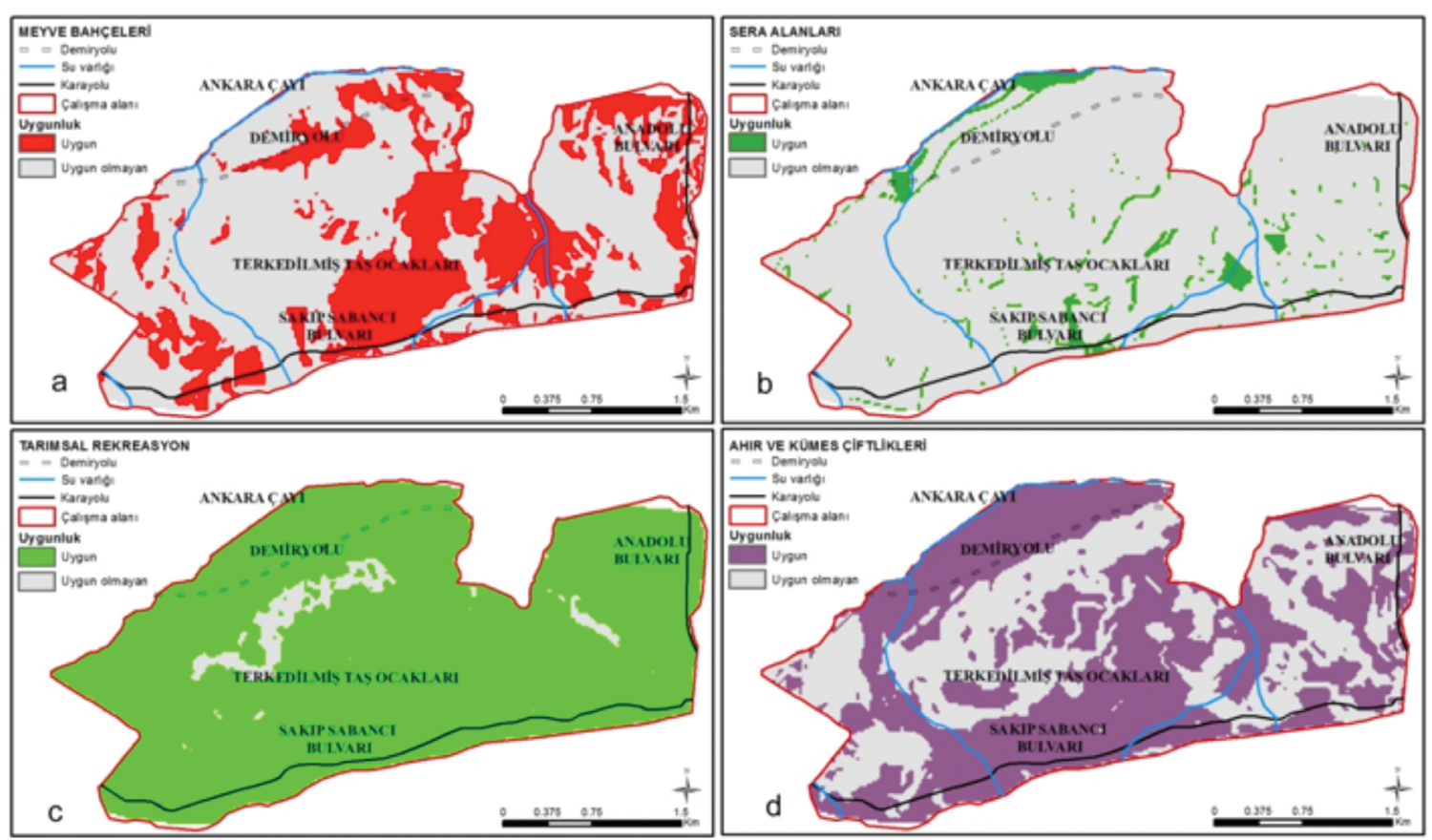

Şekil 6. Ticaret parkı kullanım alanları uygunluk analizi (a; meyve bahçeleri, b; seralar, c; tarımsal rekreasyon, d; ahır ve kümes çiftlikleri)

Figure 6. Trade park use areas suitability analysis (a; fruit garden, b; greenhouse, c; agricultural recreation, d; farms) 


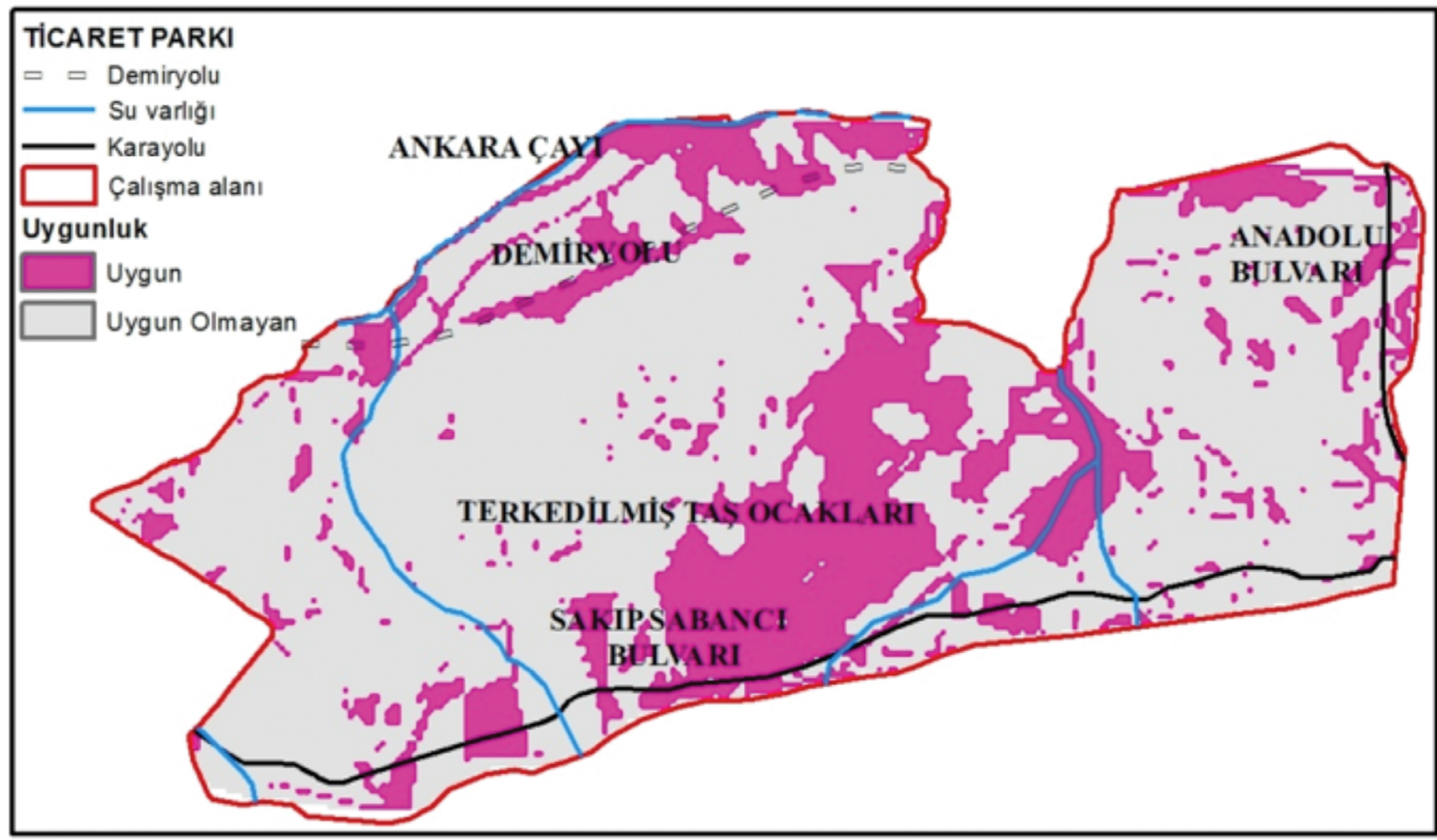

Şekil 7. Ticaret Parkına uygun alanlar

Figure 7. Trade Park suitability areas

Belirlenen bu birimlerin mekânsal dağılımları için uygunluk analizleri yapılarak öneriler geliştirilmiştir.

\section{Ticaret Parkı}

Agropark planlamasında ticaret parkı üretim ve rekreatif faaliyetlerin gerçekleştirildiği yer olarak belirtilmiştir (Smeets ve ark. 2011). Bu bağlamda araştırma kapsamında; meyve bahçeleri, üretim seraları, ahır ve kümes hayvancılığı ile tarımsal rekreasyon faaliyetleri için uygunluk analizleri gerçekleştirilmiştir. Uygunluk analizleri için kullanılan parametreler Çizelge 4'de gösterilmiştir.

Gerçekleştirilen analizler doğrultusunda çalışma alanının \%35'i meyve bahçeleri, $\% 6$ 'sı üretim seraları, \%58'i ahır ve kümes hayvancılığı ve \%94'ü tarımsal rekreasyona uygun olduğu görülmüştür (Şekil 6).

Agropark planlamasında tüm kullanım alanları için mekânsal belirlemeler yapılmalı ve mekanların bağlantıları sağlanmalıdır. Bu kapsamda tüm kullanım alanları birleştirilerek ticaret parkı birimleri için uygun bölgeler Şekil 7'de gösterilmiştir.

\section{İş Merkezi}

Agropark planlamasında ticaret parkından elde edilen ürünlerin satışının gerçekleştirildiği birimleri ve tarımsal aktivitelerin düzenlendiği alanları kapsamaktadır. Agropark kapsamında gerçekleştirilecek aktivitelerin planlaması ve tanıtımı bu alanda gerçekleştirilmektedir. Ayrıca fuarlar, gösteri alanları ve karşılama birimleri yer almaktadır. İş merkezi birimleri ile birlikte yatırımcının alana dikkatinin çekilmesi sağlanarak tarımla, teknoloji ve sanayi sektörlerinin birleştirilmesi sağlanabilecektir.

İş merkezi birimleri için uygun alanlar, Ankara Çayı'nın faaliyetlerden etkilenmesini önlemek amacıyla Ankara Çayı'ndan 1 km uzaklık ve Anadolu Bulvarı ile Sakıp Sabancı Bulvarına olan yakınlık göz önünde bulundurularak belirlenmiştir. En uygun yerlerin Anadolu Bulvarı'na yakın bölgeler olduğu görülmektedir (Şekil 8).

\section{Merkezi İşlem Birimi}

Üretim ve işleme fonksiyonlarının girdi ve çıktılarını sağlayan alt yapı ağıdır. Agroparkların sıfır atık politikası merkezi işlem birimi kurularak gerçekleştirilmektedir. Her bir atık malzemenin geri dönüşümü üzerine kuruludur. İşlevsel ve estetik olmalıdır.

Merkezi işlem birimi tasarlanırken, tüm üretim ve işleme fonksiyonları arasındaki bağlantıyı sağlamasına yerel ve bölgesel intiyaçları karşılayabilecek kapasitede olmasına ve üretim atıklarının kullanımını politik ve sektörel olarak teşvik edici olmasına dikkat edilmelidir (Smeets ve ark. 2011). 


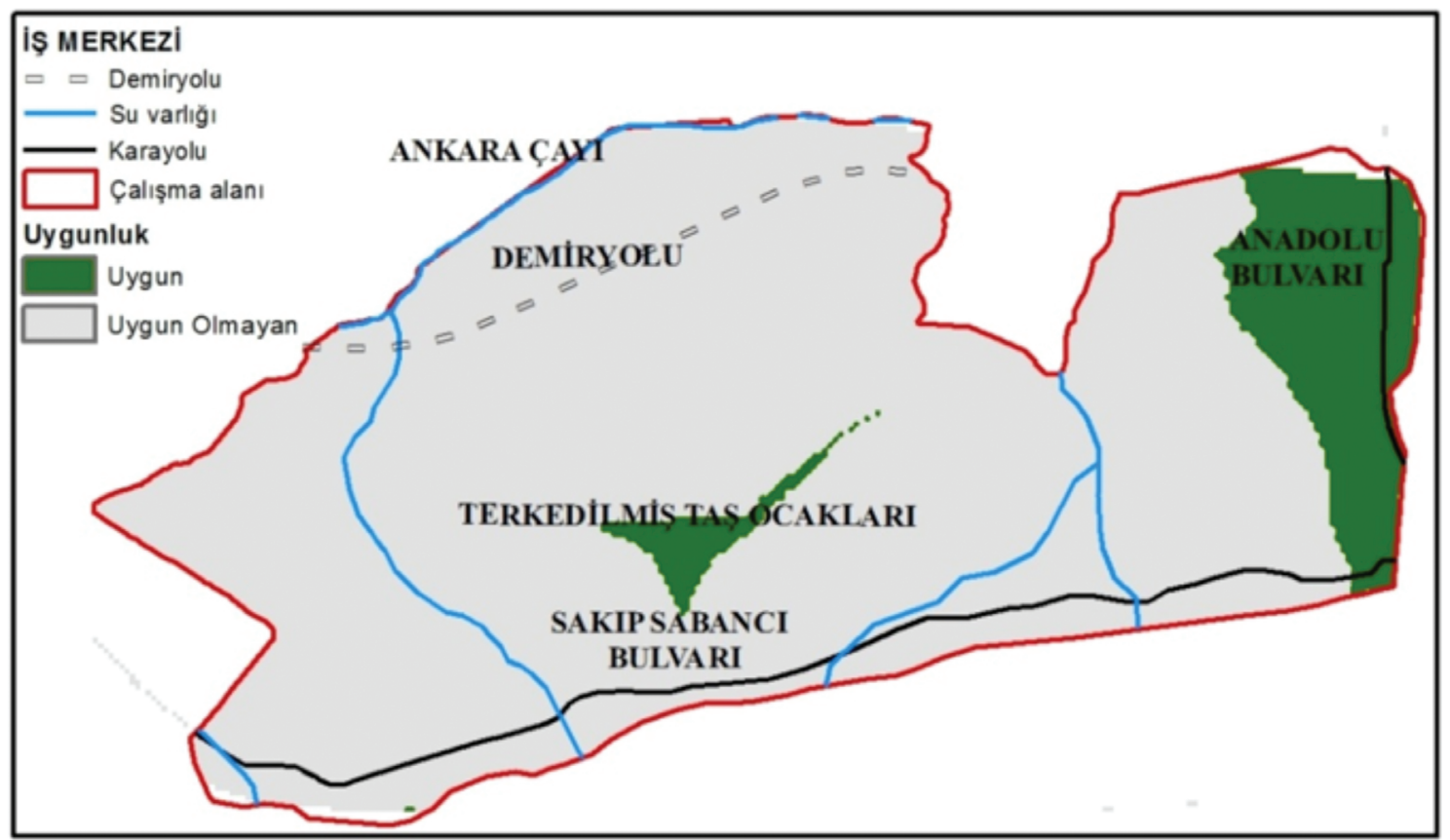

Şekil 8. İş merkezine uygun alanlar

Figure 8. Business park suitability areas

Merkezi işlem birimi yenilenebilir enerjinin kullanımını desteklemektedir. Bu bağlamda, ısıtma ve soğutma metotlarında biyogaz üretimini, su kaynaklarının etkin kullanımı için yağmur suyu toplanmasını ve depolamasını, atık suların geri dönüşümünü, organik gübre ve toprak yapı malzemelerinin üretimini sağlayacak tesisler yer almalıdır.
Merkezi işlem biriminin sürdürülebilirliği için ticaret parkı ve iş merkezindeki fonksiyonlardan ortaya çıkan atıkların miktarı hesaplanmalı elde edilecek enerji kilowatt (kw) olarak belirlenmelidir. Agroparktaki birimlerin de intiyacı olan enerji hesaplanarak verime göre kullanım alanına karar verilmelidir (Baardwijk ve ark. 2003).

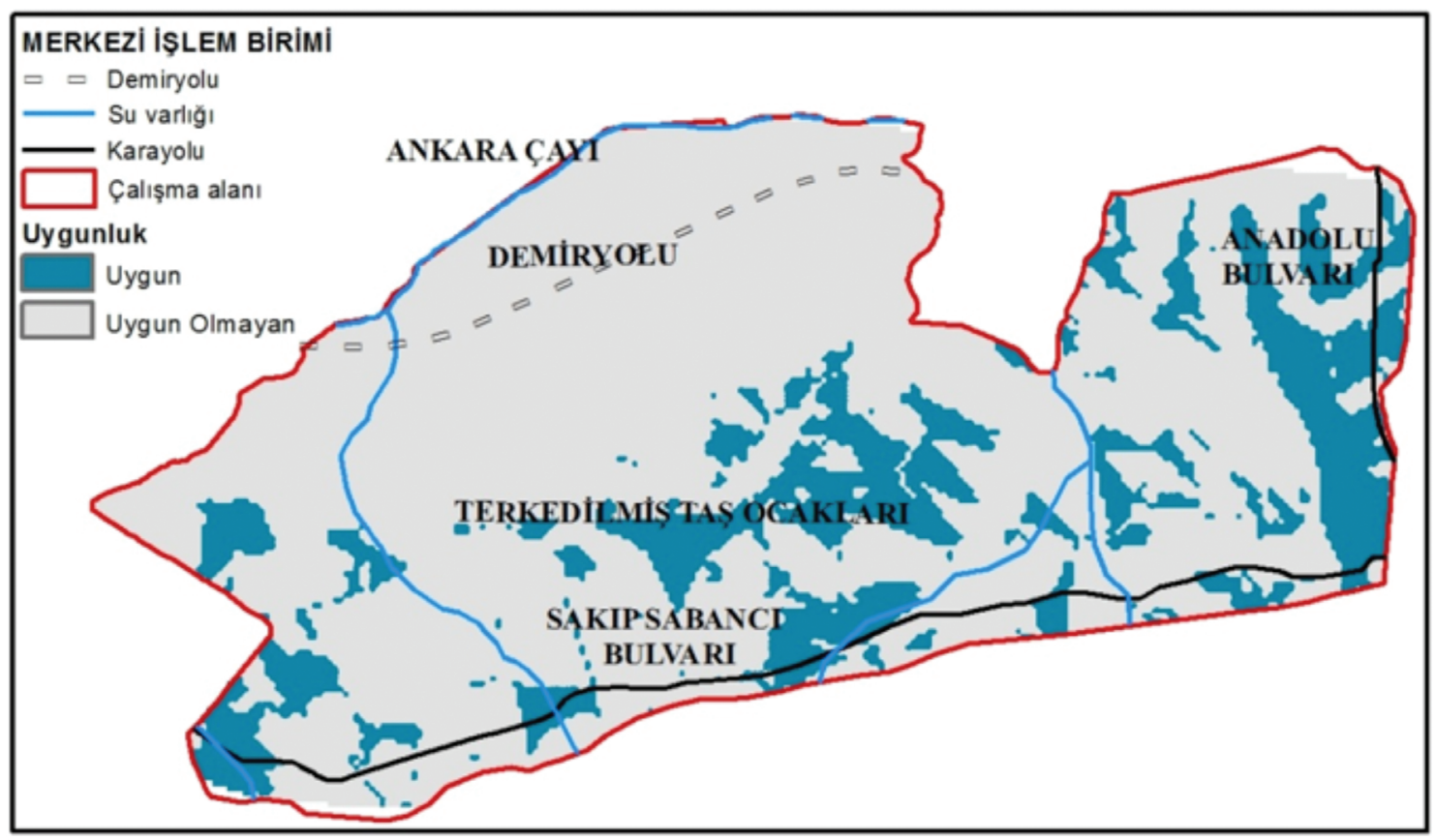

Şekil 9. Merkezi işlem birimine uygun alanlar

Figure 9. Central processing unit suitability areas 
Merkezi işlem birimi agroparkın tüm birimlerini bir ağ gibi örmelidir. Ancak enerjinin dağıtımının sağlandığı ve biyogaz tesislerinin yer alacağı bölgelerin belirlenmesi için mekânsal analiz gerçekleştirilmelidir. $\mathrm{Bu}$ bağlamda uygun olan yerler; güney, güneydoğu, güneybatı ve doğu bakarlı, rüzgârdan etkilenmeyen veya çok az etkilenen alanlar ile ulaşım güzergahlarına yakın ve su kaynaklarına uzak olma gibi parametreler kullanılarak belirlenmiştir (Alçiçek ve Demiruluş 1994). Bu bağlamda merkezi işlem birimine uygun alanların araştırma alanında terk edilmiş taş ocaklarının bulunduğu alan, Anadolu Bulvarı'nın yakın çevresi ve alanın batısında kalan alanların uygun olduğu görülmektedir. Ancak merkezi işlem birimi ticaret parkı ve iş merkezi arasındaki bağlantıyı sağlayan bir omurga olduğu için en uygun alanın terk edilmiş taş ocaklarının bulunduğu bölüm olarak belirlenmiştir (Şekil 9).

\section{Sonuç}

Yüksek verim ve ürün kalitesi, büyük pazarlama hacmi, dağıtım ve pazarlamada karın en yüksek seviyeye çıkarılmasına odaklanan agroparklar, dünyada hızla artış göstermektedir (Vargas ve ark. 2014). Ülkemizde ise Mustafa Kemal Atatürk önderliğinde kurulan tarımsal sistemin en önemli örneklerinden olan AOÇ, tarım ve hayvancılığa kurulduğu zamanlardaki bilim ve teknolojinin gerektirdiği tüm tekniklerin aktarılmasını sağlayarak ürün çeşitliliği ve verimin artııılabileceğinin kullanım dışı ve verimsiz arazilerin ıslah edilebileceği gösteren (Anonim 2009) ilk sistematik çiftlik örneğidir. Görüldüğü üzere Türkiye'de agropark temelleri AOÇ'nin 1925 yılında kurulmasıyla atılmıştır. Ancak hızlı kentleşme ve artan nüfus ile bu yaklaşımdan uzaklaşılmış, sanayi ve teknolojideki gelişmeler AOÇ'ne aktarılamamıştır.

Araştırma ile dünyadaki bu tarımsal eğilimin, AOÇ kuruluş felsefesi doğrultusunda terkedilmiş taş ocaklarına uygulanması önerilmiştir. Araştırmada öncelikle taş ocağı etkilerinin azaltılması ve alanın duraylıı̆̆ının artırılması ve topografik özelliklerinin yakın çevresi ile uyumlu hale getirilmesi hedeflenmiştir. Bu aşamadan sonra teknolojik, sistemli ve sürdürülebilir bir agropark örneği için alanın uygunluğu değerlendirilmiştir. Bu kapsamda yapılan analizler sonucunda araştırma alanının, agropark olarak planlanabileceği kanıtlanmıştır. Kent halkına taze ve organik ürünler sunan ticaret parkı, tarım odaklı fuarlar ile sektörel buluşmaların gerçekleştirilmesini sağlayan iş merkezi, agroparkın enerjini dönüşümün sağlarken oluşturulan ağ sistemi ile ekolojik gezinti yolları, bisiklet güzergahları, enerji ve gıda dönüşümünü gösteren eğitim yollarının uygulanmasına olanak sağlayan merkezi işlem birimi, multidisipliner ve transdisipliner bir yaklaşımla planlanmalıdır. Böylece AOÇ'nin kuruluş amaçlarına uygun olarak korunması, toprak bütünlüğü, kent halkın için alternatif rekreasyonel faaliyetler, kent-kır bütünlüğü, tarım sektörlerinin canlanması, yeni üretim tekniklerinin geliştirilmesi sağlanabilecektir. Ayrıca yıllarca atıl kalan ve verimsizleşen toprak örtüsünün rehabilitasyonu sonucu Ankara doğal bitki örtüsü ile uyumlu bitkilendirme çalışmalarının yapılması, planlanan meyve bahçeleri ve tarımsal rekreasyon alanlarının oluşturduğu geniş yeşil örtüler ile kentsel yeşil alan sistemine katkıda bulunabilecektir. Ankara'nın en önemli su kaynağı olan Ankara Çayı'nın, planlama kapsamında değerlendirilmesi ile biyolojik ıslah çalışmalarının yapılması ve bu doğrultuda rekreasyon ve sulama amacıyla kullanılması gerçekleştirilebilir.

Çevreye sıfır atık politikasıyla kurulan, ekolojik koruma sağlayan, ekonomik ve estetik değerleri içeren agroparklar, çevresel ya da insan etkileriyle bozulmuş peyzajların, faaliyeti bitmiş maden sahalarının, onarım çalışmalarında, alternatif olarak düşünülmelidir. Ayrıca istihdam olanakları ile madencilik sonrasında da ekonomik kazanımlar devam edecek, küçük ölçekte bölgeye büyük ölçekte ise ülke ekonomisine ve refahına katkılar sağlayacaktır.

Agroparklar, bozulmuş, atıl alanların yanında özellikle parçalı olarak bulunan tarım alanlarının birbirine benzer kümeler halinde bağlanmasıyla da kurulabilir (Wolf ve Veen 2015): Ancak bu uygulamanın dinamikleri, etkileri ile ortaya çıkan sonuçlar doğru ve akılcı olarak değerlendirilerek politikaların oluşturulması gerekmektedir. Bu kapsamda gıda sistemleri içinde yenilikçi yaklaşımlar sunan agroparkların politikacılar ve toplum tarafından benimsenmesi ve bakış açısı geliştirilmelidir (Hoes ve Reeger 2014). Bu nedenle bilimsel çalışmalar artıııımalı ve bilgi alt yapısı kuvvetlendirilmelidir. Söz konusu alt 
yapının oluşturulmasına araştırmanın katkılar sunacağı düşünülmektedir. Aynı zamanda, multidisipliner bir çalışma gerektiren agropark planlama ve uygulaması için farklı bilim dallarında araştırmalar yapılması gerekmektedir. Bu kapsamda araştırma, yapılacak çalışmaların yöntemine örnek olacaktır.

\section{Kaynaklar}

Açıksöz S., 2001. Ankara'da kentsel tarım kapsamında Atatürk Orman Çiftliği'nin günümüz koşullarında yeniden değerlendirilmesi üzerine bir araştırma. Doktora Tezi, Ankara Üniversitesi, Fen Bilimleri Enstitüsü (Basılmamış), Ankara, s. 3-95, 122-232

Akpınar N., 1994. Açık kömür ocaklarında çevresel etkilerin değerlendirilmesi ve doğa onarımı çalışmalarının Milas-Sekköy Açık Kömür Ocağı örneğinde irdelenmesi. Doktora tezi, Ankara Üniversitesi, Fen Bilimleri Enstitüsü, Peyzaj Mimarlığı Anabilim Dalı (Basılmamış), Ankara

Akpınar N., 2000. Taş ocaklarının çevresel etkileri ve bu alanların onarımı. 2000'li Yıllarda Yaşadığımız Çevre ve Peyzaj Mimarlığı Sempozyumu, 2426 Mayıs, Ankara s. 191-199

Akpınar N.,Başal M., Karadeniz N., Talay İ., Kılıç N., Atalay A. ve Tanrıvermiş H., 2004. Adıyaman Ziyaret Çayı havzası tarımsal potansiyelinin belirlenmesi ve enerji etkin peyzaj planlama bağlamında arazi kullanım desenin oluşturulması. TÜBITAK, Tarım Orman ve Gıda Teknolojileri Araştırma Grubu, Ankara, s. 83 - 84

Alçiçek A. ve Demiruluş H., 1994. Çiftlik gübrelerinin biyogaz teknolojisinde kullanılması. Ekoloji Çevre Dergisi,13: 5-9

Anonim, 2005. Türkiye'nin belirli bir havzasında USLE ile yıllık toprak kayıplarının tahmin edilmesi. Ankara Üniversitesi Toprak Anabilim Dalı Ders Notu (Basılmamış), Ankara

Anonim, 2009. Atatürk Orman Çiftliği'nin geleceğini tartışıyoruz. Ankara Barosu Yayınları, Ankara, s. 9-79

Anonim, 2017. http://www.karsiyaka.bel.tr/tr/ haberler /cumhuriyette-muhtesem-donusum (Erişim tarihi 13.05.2017)

Anonymous, 2012a. http://www.butchartgardens. com/gardens (Erişim Tarihi: 14.01.2012)

Anonymous, 2012b. http://en.wikipedia.org/wiki/ Haller_Park (Erişim Tarihi: 14.01.2012)

Anonymous, 2017 http://news.ucsc.edu/2015/03/ rev-spring-15-alumni-weekend.html (Erişim tarihi: 13.05.2017)
Arcak Ç., Keçeci M., Usul M. ve Karabulut A., 2002. Atatürk Orman Çiftliği detaylı toprak etüdü ve haritalaması, Köy Hizmetleri Genel Müdürlüğü, Toprak Gübre ve Su Kaynakları Araştırma Enstitüsü Müdürlüğü, Ankara

Arık F., Öztürk A., Diken A., Eren Y., Nalbantçılar T. ve Tor K., 2010. Yazır Fayı (SelçukluKonya) üzerindeki terkedilen taş ocakları ve jeopark projesi. http://web.firat.edu.tr/ jeokoruma/jeo/PDF/F.\%20ARIK\%201.pdf (Erişim Tarihi: 12.02.2010).

Atak E. ve Şahin Z., 2004. Atatürk Orman Çiftliği'nin 79 yılı ve çiftliğin korunmasına yönelik politika arayışları. Planlama Dergisi 2004(3): 80-88

Baardwijk I., Bogers M., IJdema T., Laarhoven J., 2003. HetAgroparkEenIntegrale Benaderıng. Eindhoven University InnovationScience 0E411 Integrative Project, Netherlands

Carsjens G. J., 2015. Food in space: the spatial organization of food systems. AgricEnglnt: CIGR Journal, Special issue 2015: $18^{\text {th }}$ World Congress of CIGR: 10-17

Ceylan H. ve Özkahraman T., 2000. Madencilik faaliyetlerinde çevresel planlama ve uygulanabilecek doğaya yeniden kazandırma alternatifleri. Türkiye 12. Kömür Kongresi, 23-26 Mayıs 2000, Ereğli s: 91100

Çelik M., 2006. Atatürk Orman Çiftliğinin işletmecilik anlamında işleyişi ve kooperatiflerle olan ilişkileri. Yüksek Lisans Tezi, Trakya Üniversitesi, Fen Bilimleri Enstitüsü (Basılmamış). Tekirdağ, s: 5-12

Gezer E., 2006. Yalova yöresindeki çiçeklik seraların teknik özelliklerinin belirlenmesi. Yüksek Lisans Tezi, Trakya Üniversitesi, Fen Bilimleri Enstitüsü (Basılmamış), Tekirdağ, s: 5

Hoes A-C. and Regeer B.J., 2014. Adoption of Novelties in a pluralist society: Exploring an agropark case study. Journal of Environmental Policy \& Planning 17(1): 3-24

Kliebisch C., 2009. MasterplanAgro-Park / Gartenbaugebiet (Pilotprojektionfürden KreisKleve)- Zusammenfassung.AFC Management Consulting AG, Bonn

Özcan A., 2009. Ankara-Hasanoğlan taş ocaklarının onarımı ve kentsel kullanım açısından değerlendirilmesi üzerine bir araştırma. Doktora Tezi, Ankara Üniversitesi, Fen Bilimleri Enstitüsü (Basılmamış), Ankara, s. 4-29, 94 
Öztoprak İ., 2006. Atatürk Orman Çiftliği'nin tarihi. Atatürk Araştırma Merkezi, Ankara, s.29, 63, 105-123

Smeets, P.J.A.M., 2011. Expedition agroparks. Research by design into sustainable development and agriculture in the network society. PhD thesis Wageningen University, Wageningen Academic Publishers, Wageningen

Smeets P.,Mansfeld M., Chonghua Z., Loohuis R O., Broeze J., Buijs S., Moens E., Latesteijn H., Steekelenburg M., Stumpel L., Bruinsma W., Megen T., Mager S., Ch,rst, aens P. and Heijer H., 2011. Master plan Greenport Shanghai Agropark. Shanghai Industrial Inverstment Corporation Alterra Wageningen University and Research Center

Taşçıŏlu S.,2011. Taş ocağı faaliyetlerinin peyzaj üzerine etkileri ve onarım süreci: Antalya ili örneği. Seminer, Ankara Üniversitesi, Fen Bilimleri Enstitüsü (Basılmamış), Ankara, s. 6-7
Tıknazoğlu B., 2010. Sığırcılık. Samsun İ Tarım Müdürlüğü, Çiftçi Eğitimi ve Yayım Şubesi, Samsun, s. 58-61

Vargas-Hernandez J.G. and HernandezMedina D.,2014.Application of the Based Resources Theory in Agropark Ahualulco. Comprehensive Research Journal of Management and Bussiness Studies, Vol. September, p. 1-4

Wolf P.and Veen E., 2015. Connecting global ambitions to regional realities- A process review of agropark development in the Noordoostpolder. The malleability and unpredictability of regional transitions: a systematic approach for reflection and learning. Wageningen University and Research, Netherlands 